\title{
PENGEMBANGAN TEKNIK DIAGNOSA PENYAKIT EPIZOOTIC ULCERATIVE SYNDROME (EUS) PADA IKAN MELALUI PENDEKATAN GEJALA KLINIS, ISOLASI PATOGEN, HISTOPATOLOGIS
}

\author{
Ade Nurdin", Khumaira Puspasari", Eka Nurdian", Tina Y. Asri", dan Taukhid") \\ ") Balai Uji Standar Karantina Ikan dan Pengendalian Mutu Hasil Perikanan (BUSKIPM) \\ Jl. Harapan I, No. 1 A, Cipayung, Jakarta Timur \\ E-mail: buski_jkt@dkp.go.id \\ *) Balai Penelitian dan Pengembangan Budidaya Air Tawar \\ Jl. Sempur No. 1, Bogor 16154
}

(Naskah diterima: 4 Januari 2012; Disetujui publikasi: 8 Mei 2012)

\begin{abstract}
ABSTRAK
Epizootic Ulcerative Syndrome (EUS) adalah penyakit pada ikan yang disebabkan oleh infeksi jamur parasitik Aphanomyces invadans. Penelitian ini bertujuan untuk mendiagnosa patogen penyebab penyakit EUS melalui perpaduan 3 (tiga) basis pendekatan, yaitu: (1) gejala klinis, (2), isolasi patogen, dan (3) histopatologis. Sebanyak 30 ekor ikan uji diinfeksi spora jamur $A$. invadans secara buatan sebanyak 100 spora/ ekor ikan melalui penyuntikan secara intra muskular (IM), dan 30 ekor lainnya diinjeksi dengan phosphate buffered saline (PBS) sebagai kontrol. Hasil penelitian menunjukkan bahwa gejala klinis yang muncul adalah timbulnya bercak-bercak merah pada tubuh ikan, selanjutnya berkembang menjadi ulser (ulcer) karena invasi hifa cendawan ke dalam otot/daging ikan. Hasil isolasi jamur dari ulser ditemukan adanya hifa aseptat dengan diameter 7,5-10,0 $\mu \mathrm{m}$; memproduksi zoospora primer berbentuk cluster achloyd dan zoospora sekunder berbentuk biflagellata. Secara histopatologis ditemukan adanya invasi hifa dan sel granuloma (mycotic dermatitis granulomatosis).
\end{abstract}

KATA KUNCl: diagnosa, EUS, gejala klinis, isolasi, dan histopatologi

ABSTRACT: Development of diagnosis technique of Epizootic Ulcerative Syndrome (EUS) on fish based on clinical signs, pathogen isolation, and histophatological approaches. By: Ade Nurdin, Khumaira Puspasari, Eka Nurdian, Tina Y. Asri, and Taukhid

Epizootic Ulcerative Syndrome (EUS) is an infectious disease of fish caused by parasitic fungi, Aphanomyces invadans. The research with the objective to identify aetiological agent of Epizootic Ulcerative Syndrome (EUS) on fish by using integration of clinical signs, pathogen isolation, and histopathological approach has been done. Thirty fish were injected intra muscularly with the spores of $\boldsymbol{A}$. invadans at the dose of 100 spores/fish, and the same amount of fish were injected with phosphate buffered saline was used as a control group. The results show that artificial infection causing red spots on external body of fish, and then become ulceration. Isolation of the fungal shows an aseptate fungal hyphae with the diameter of 7.5-10.0 $\mathrm{\mu m}$; the fungi produce a cluster achloyd form of primary zoospore, and biflagellate secondary zoospore. Histopathologically, A. invadans infection was characterized by mycotic dermatitis granulomatosis with the fungal hyphae at the center of its granulomatosis cells.

KEYWORDS: diagnosis, EUS, clinical signs, isolation, dan histopathology 


\section{PENDAHULUAN}

Kasus penyakit jamur pada ikan di Indonesia umumnya belum dianggap serius; karena munculnya kasus tersebut lebih banyak difasilitasi oleh kondisi lingkungan yang buruk, malnutrisi, penanganan ikan yang kurang sempurna, atau akibat patogen penginfeksi primer lain seperti parasit, bakteri dan virus. Beberapa jenis jamur penyebab penyakit pada ikan berpotensi sebagai parasit yang dapat mengakibatkan kematian ikan. Jenisjenis jamur tersebut antara lain Aphanomyces invandans, A. astaci, Branchiomyces sanguinis, dan $B$. demigrans.

Epizootic Ulcerative Syndrome (EUS) adalah penyakit pada ikan yang disebabkan oleh infeksi jamur parasitik Aphanomyces invadans (Roberts et al., 1994). Office International des Epizooties (OIE), badan dunia yang bertanggung jawab untuk mengontrol kesehatan hewan termasuk hewan akuatik mendefinisikan EUS sebagai "kondisi epizootik musiman pada ikan air tawar dan/atau payau yang disebabkan oleh agen infeksius, ditandai dengan adanya infeksi invasif oleh Aphanomyces invadans dan ulser yang sangat tipikal disertai respon granuloma". Selanjutnya dikatakan bahwa pada beberapa kasus, ditemukan pula keterlibatan infeksi oleh parasit, rhabdoviruses serta bakteri gram negatif sebagai penginfeksi sekunder pada ulser EUS. Hingga kini OIE masih menetapkan penyakit EUS sebagai salah satu penyakit ikan yang menjadi perhatian internasional (notifiable listed disease). Pemerintah Indonesia melalui Kementerian Kelautan dan Perikanan menetapkan jenis penyakit ini sebagai salah satu Hama dan Penyakit Ikan Karantina (HPIK) golongan 1 berdasarkan KepMen KP.03/ Men/ 2010.

Selama lebih dari 25 tahun, EUS telah mengakibatkan kerugian besar pada perikanan di kawasan Asia (Hatai et al., 1977; Hatai \& Egusa, 1978; Tonguthai, 1985; Roberts et al., 1990; Roberts et al., 1993) dan Australia (Fraser et al., 1992; Callinan, 1994). Sebelumnya penyakit tersebut diberi nama yang berbedabeda seperti "mycotic granulomatosis (MG)" di Jepang (Hatai et al., 1977; Hatai \& Egusa, 1978), "red spot disease (RSD)" di Australia (Callinan, 1994; Fraser et al., 1992), dan "Epizootic Ulcerative Syndrome (EUS)" di Asia Tenggara dan Selatan (Roberts et al., 1993; Willoughby \& Roberts, 1994; Willoughby et al.,
1995). Nama yang terakhir selanjutnya disepakati sebagai nama definitif dari penyakit tersebut (Lilley et al., 1997).

Wabah EUS sedikitnya telah dilaporkan di 18 negara Asia-Pasifik (Lilley et al., 1998), dan menimbulkan kerugian ekonomi yang sangat besar baik pada ikan budidaya maupun ikan di perairan umum yang merupakan sumber protein masyarakat di beberapa negara yang mengalaminya (Roberts et al., 1994). Wabah penyakit tersebut pertama kali terjadi pada 1971 di Jepang (Miyazaki \& Egusa, 1972), kemudian menyebar ke beberapa negara di Asia dan Australia. Di kawasan Asia Tenggara termasuk Indonesia, wabah EUS terjadi pada tahun 1980-an; dan wabah yang paling serius terjadi di Thailand pada 1982-1983, dengan kerugian diperkirakan mencapai US\$ 9 juta (Tonguthai, 1985). Lebih dari 100 jenis ikan antara lain ikan mas, tambakan, gurame, nila, lele, betutu, gabus, sepat, betok, jelawat, dan bandeng dilaporkan peka terhadap infeksi $A$. invadans (Pradhan et al., 2007). Namun selain kerugian yang ditimbulkannya, pandemi EUS juga memberikan dampak positif terhadap pengembangan penelitian penyakit ikan serta fasilitas diagnosa (laboratorium) di kawasan Asia, baik yang dibiayai oleh pemerintah maupun organisasi internasional.

Identifikasi jamur parasitik pada ikan untuk keperluan diagnosa definitif masih tertinggal dibandingkan dengan bakteri atau virus. Selama ini, identifikasi jamur parasitik lebih banyak didasarkan pada beberapa indikator seperti morfologi hifa, morfologi unit reproduksi, siklus hidup, serta tipe spora yang dihasilkannya. Namun akhir-akhir ini sudah mulai dikembangkan teknik identifikasi dan deteksi jamur parasitik pada ikan yang berbasis molekuler. Office International des Epizooties (OIE, 2010), merekomendasikan bahwa untuk diagnosa penyakit EUS pada ikan didasarkan pada gejala klinis dan dikonfirmasi secara histopatologis dan/atau isolasi patogen dari jaringan internal ikan yang menunjukkan gejala klinis.

Penelitian ini bertujuan untuk mengembangkan dan mengaplikasikan (verifikasi metode) teknik diagnosa penyakit EUS pada ikan melalui perpaduan 3 (tiga) basis pendekatan, yaitu (1). gejala klinis, (2). isolasi patogen, dan (3). histopatologis. Perpaduan antara pendekatan gejala klinis dengan histopatologis dan/atau isolasi patogen 
merupakan metode standar emas (gold standard) teknik diagnosa penyakit EUS yang direkomendasikan oleh OIE (2010).

\section{BAHAN DAN METODE}

Penelitian ini dilakukan pada skala laboratorium, prosedur pelaksanaan kegiatan secara garis besar adalah sebagai berikut:

\section{Ikan Uji dan Isolat Jamur}

Ikan uji yang digunakan pada penelitian ini adalah ikan gurame (Osphronemus gouramy) ukuran 10-15 cm yang berasal dari satu "batch" pembenihan atau populasi, dan diasumsikan "specific pathogen free (SPF)" terhadap patogen target berdasarkan hasil diagnosa secara klinis dan mikologis yang dilakukan secara acak terhadap populasi sampel ikan sebanyak 10\% (8 ekor) sebelum proses aklimatisasi.

Pemberian pakan dilakukan secara ad libitum sebanyak $3 \mathrm{kali} / \mathrm{hari}$ (pagi, siang, dan sore). Jenis pakan yang digunakan adalah pakan komersial (pelet apung) dengan kadar protein kasar sebesar $\pm 20 \%$, dan disuplementasi dengan daun talas secukupnya yang diberikan setiap 2 hari sekali.

Isolat jamur parasitik Aphanomyces invadans yang digunakan pada penelitian ini merupakan koleksi biakan jamur parasitik pada Balai Uji Standar Karantina Ikan dan Pengendalian Mutu Hasil Perikanan (BUSKIPM), Pusat Karantina Ikan. Sebelum digunakan sebagai patogen uji, isolat jamur tersebut terlebih dahulu diinfeksikan ke ikan gurame "SPF" terhadap A. invadans yang dilakukan sesuai kaidah Postulate Koch's. Setelah muncul gejala spesifik akibat infeksi jenis jamur tersebut, segera dilakukan reisolasi, pemurnian, dan rekarakterisasi hingga diperoleh isolat jamur yang siap untuk digunakan sebagai patogen uji pada penelitian ini.

\section{Perlakuan}

Jumlah ikan uji yang digunakan adalah sebanyak 60 (enam puluh) ekor yang dibagi menjadi 2 kelompok yaitu perlakuan dan kontrol, masing-masing sebanyak 30 ekor. Masing-masing kelompok dipelihara dalam 3 akuarium/wadah dengan kepadatan 10 ekor/wadah. Perlakuan yang diterapkan pada penelitian ini adalah pemberian infeksi buatan pada ikan uji dengan spora jamur parasitik $A$. invadans sebanyak 100 spora/ekor $(0,1 \mathrm{~mL}$
Iarutan spora) yang diberikan melalui penyuntikan secara intra muskular (IM). Sedangkan pada kelompok lainnya disuntik dengan larutan phosphate buffered saline (PBS) sebanyak 0,1 mL/ekor sebagai kontrol.

\section{Pengamatan}

Pengamatan terhadap tingkah laku, gejala klinis dan mortalitas ikan uji dilakukan setiap hari hingga akhir periode pengujian yang berlangsung selama 14 hari. Selain itu, pengambilan sampel untuk diagnosa/ identifikasi patogen target melalui teknik pengamatan preparat basah (squash), isolasi dan histopatologi dilakukan setiap 2 hari sebanyak 1 ekor/wadah hingga akhir pengamatan. Pengambilan sampel pada kelompok perlakuan dilakukan secara selektif terhadap individu ikan uji yang menunjukkan tingkah laku dan/atau gejala klinis paling nyata; dan individu yang digunakan sebagai sampel analisis "diasumsikan" mengalami kematian. Sedangkan pengambilan sampel ikan pada kelompok kontrol dilakukan secara acak, dan "diasumsikan" tetap bertahan hidup hingga akhir penelitian.

\section{Gejala Klinis}

Tingkah laku dan gejala klinis ikan uji dari masing-masing kelompok diamati setiap hari setelah pemberian perlakuan, indikator yang dielaborasi pada kegiatan tersebut antara lain: perubahan respon nafsu makan, warna tubuh, pergerakan renang, serta ada/tidaknya bintik merah dan/atau ulcer pada permukaan tubuh. Perubahan tingkah laku dan gejala klinis secara umum dari masing-masing kelompok ikan uji dirangkum secara tabulatif, dan selanjutnya dianalisa secara deskriptif.

Ulcer berwarna merah atau keabu-abuan yang diikuti dengan nekrosis berwarna kecoklatan merupakan salah satu indikator adanya infeksi jamur parasitik $A$. invadans, untuk selanjutnya secara individual dilakukan pemeriksaan secara langsung (preparat basah/ squash), isolasi dan histopatologi.

\section{Isolasi dan Pengamatan Sporulasi Jamur Parasitik}

Isolasi jamur A. invadans dilakukan terhadap individu ikan yang menunjukkan adanya bintik merah dan/atau ulcer pada tubuh ikan. Secara aseptik, ulcer pada permukaan tubuh ikan diiris vertikal hingga di bawah jaringan 
kulit ( $\pm 3 \mathrm{~mm}$ ), kemudian dilakukan pengirisan horizontal di bawah luka, lalu jaringan yang mengalami ulcer tersebut diangkat. Jaringan otot/daging di bawah ulcer yang telah diangkat, diambil dalam bentuk "flat" sekitar 2-5 $\mathrm{mm}^{3}$. Selanjutnya potongan jaringan tersebut diinokulasi pada media Glucose Pepton Agar (1 liter media mengandung glucose 3 gram, pepton 6 gram, dan agar 12 gram) yang ditambahkan Penicillin K (100 unit/mL) dan Oxolinic Acid $(100 \mu \mathrm{g} / \mathrm{mL})$ di dalam petridish, dan untuk selanjutnya formulasi media tersebut disingkat media GPOX Agar. Cawan petri tersebut kemudian disegel menggunakan parafilm dan diinkubasi pada suhu $25^{\circ} \mathrm{C}$ selama 7 (tujuh) hari.

Pengamatan pertumbuhan jamur dilakukan setiap hari dengan menggunakan bantuan inverted microscope. Hifa yang tumbuh segera dipindahkan ke media yang baru hingga diperoleh isolat jamur yang murni. Isolat jamur yang sudah murni ditumbuhkan pada media Glucose Pepton Agar (GPA) tanpa penambahan antibiotik, dan untuk mempertahankan isolat tersebut dilakukan proses sub-kultur setiap 7 hari pada media GPA. Selain itu, penyimpanan isolat juga dilakukan pada suhu refrigerator $\left(4^{\circ} \mathrm{C}-8^{\circ} \mathrm{C}\right)$, dan proses sub-kultur untuk teknik penyimpanan ini dilakukan setiap bulan.

Sporulasi jamur dilakukan pada media cair dengan prosedur sebagai berikut. Ujung miselium jamur pada media agar dipotong dengan ukuran 5-10 $\mathrm{mm}^{3}$ sehingga diperoleh "mat" (media agar berbentuk balok). Mat-mat tersebut selanjutnya ditumbuhkan dalam media cair Glucose Pepton Yeast (GPY) Broth (1 liter media mengandung glucose $3 \mathrm{gram}$, pepton $6 \mathrm{gram}$, dan yeast extract $0,5 \mathrm{gram}$ ) dan diinkubasi pada suhu $25^{\circ} \mathrm{C}$ selama $2-3$ hari. Mat-mat yang sudah dipenuhi oleh hifa jamur selanjutnya dicuci dengan air kolam steril secara berulang-ulang untuk menghilangkan nutrien. Selanjutnya, mat disimpan dalam air kolam steril dan diinkubasi pada suhu kamar $\left( \pm 25^{\circ} \mathrm{C}\right)$ selama $12-24$ jam. Produksi serta proses pelepasan spora (zoospora primer dan sekunder) dari hifa jamur fertil dapat diamati di bawah mikroskop setelah proses inkubasi berlangsung lebih dari 6 jam.

\section{Histopatologi}

Proses pembuatan preparat histopatologi dilakukan sesuai prosedur standar yang meliputi: trimming, pemrosesan jaringan dalam tissue processor, infiltrasi/blocking menggunakan parafin, pemotongan block parafin, dan penempelan jaringan pada gelas objek serta pewarnaan. Pewarnaan dilakukan dengan Hematoxylin dan Eosin (H\&E), serta pewarnaan dengan Grocott's Methanamine Silver (GMS) yang bertujuan untuk memperjelas adanya typical granuloma dan invasive hypae dalam jaringan yang terinfeksi jamur A. invadans.

\section{Analisa Data}

Data perubahan tingkah laku dan gejala klinis ikan uji disajikan dalam bentuk tabel dan dianalisis secara deskriptif. Hasil isolasi, sporulasi, dan karakterisasi jamur parasitik disajikan dalam bentuk tabel, dan selanjutnya dianalisa secara deskriptif.

\section{HASIL DAN BAHASAN}

\section{Gejala Klinis (Patologis-Anatomis)}

Pada hari ke-2 pasca perlakuan, kelompok ikan yang diberi infeksi buatan mulai menunjukkan perubahan tingkah laku abnormal seperti nafsu makan berkurang, hiperaktif, berenang dekat permukaan air, serta pergerakan renang yang kurang terarah. Lilley et al. (2001) menyatakan bahwa tingkah laku dan gejala klinis pada fase infeksi awal adalah ikan menjadi lesu, nafsu makan berkurang bahkan hilang, mengapung di bawah atau permukaan air dan berenang dengan kepala keluar dari air. Perubahan tingkah laku dan gejala klinis yang muncul selama periode pengamatan (10 hari) pasca pemberian perlakuan, secara sederhana disajikan pada Tabel 1. Ditemukan juga bintik merah, luka kehitaman seperti bercak atau luka yang lebih dalam, di bagian tengah berwarna merah dan di bagian pinggir berwarna putih.

Mulai hari ke-2 pasca pemberian infeksi buatan, pada kelompok tersebut juga mulai terlihat adanya bintik merah di sekitar bagian tubuh yang diinjeksi spora jamur; dan selanjutnya berkembang menjadi ulceryang serius pada hari-hari berikutnya hingga mengakibatkan kematian. Lilley et al. (2001) menyatakan bahwa pada awal infeksi terdapat area dermatitis akut membentuk warna kemerahan (rosacea). Fase selanjutnya ditunjukkan dengan ulcer pada kulit (2-4 cm) dengan hilangnya kulit luar dan sisik, hemoragi dan edema. Ulcer umumnya melingkar dan berwarna gelap, dan sering pula dijumpai ulcer yang mengarah ke tulang/menembus kulit menuju tulang. 
Tabel 1. Perubahan tingkah laku dan gejala klinis pasca pemberian infeksi buatan dengan spora jamur Aphanomyces invadans

Table 1. Behavior changes and clinical signs of fish after injected with Aphanomyces invadans spores

\begin{tabular}{|c|c|c|c|c|c|c|}
\hline \multirow{2}{*}{$\begin{array}{l}\text { Kelompok } \\
\text { Group }\end{array}$} & \multirow{2}{*}{$\begin{array}{l}\text { Indikat or } \\
\text { Indicators }\end{array}$} & \multicolumn{5}{|c|}{ Hari ke- (Days-) } \\
\hline & & 2 & 4 & 6 & 8 & 10 \\
\hline \multirow[t]{6}{*}{$\begin{array}{l}\text { Perlakuan } \\
\text { Artificial infection }\end{array}$} & $\begin{array}{l}\text { Nafsu makan berkurang } \\
\text { Decreased appetite }\end{array}$ & + & +++ & +++ & +++ & +++ \\
\hline & $\begin{array}{l}\text { Berenang dekat permukaan air } \\
\text { Swimming near the surface of water }\end{array}$ & + & ++ & +++ & +++ & ++ \\
\hline & $\begin{array}{l}\text { Hipe raktif/tidak te rarah } \\
\text { Hyperactivity/undirected }\end{array}$ & - & + & ++ & ++ & ++ \\
\hline & $\begin{array}{l}\text { Warna tubuh gelap } \\
\text { Body color dark }\end{array}$ & +++ & +++ & ++ & +++ & +++ \\
\hline & $\begin{array}{l}\text { Bintik merah } \\
\text { Red spots }\end{array}$ & ++ & ++ & - & - & - \\
\hline & Ulser (Ulcer) & & ++ & +++ & +++ & +++ \\
\hline \multirow{6}{*}{$\begin{array}{l}\text { Kont rol } \\
\text { Control }\end{array}$} & $\begin{array}{l}\text { Nafsu makan berkurang } \\
\text { Decreased appetite }\end{array}$ & + & - & - & - & - \\
\hline & $\begin{array}{l}\text { Berenang dekat permukaan air } \\
\text { Swimming near the surface of water }\end{array}$ & - & - & - & - & - \\
\hline & $\begin{array}{l}\text { Hiperaktif/tidak te rarah } \\
\text { Hyperactivity/undirected }\end{array}$ & - & - & - & - & - \\
\hline & $\begin{array}{l}\text { Warna tubuh gelap } \\
\text { Body color dark }\end{array}$ & + & - & - & - & - \\
\hline & $\begin{array}{l}\text { Bintik merah } \\
\text { Red spots }\end{array}$ & - & - & - & - & - \\
\hline & Ulser(Ulcer) & - & - & - & - & - \\
\hline
\end{tabular}

Keterangan (Note):

(-) tidak ada, (+) sedikit (7 5 ekor/wadah), (++) sedang (6-9 ekor/wadah), dan (+++) banyak (8 10 ekor/ wadah)

(-) none, (+) little (7 5 fish/container), (++) moderate (6-9 fish/container), and (+++) many (8 10 fish/ container)

Berdasarkan informasi kualitatif yang tertera pada Tabel 1 menunjukkan bahwa ikan uji pada kelompok perlakuan sudah menunjukkan perubahan tingkah laku dan gejala klinis yang nyata mulai hari ke-2 pasca pemberian infeksi buatan, selanjutnya kondisi kedua indikator tersebut semakin menguat pada hari-hari berikutnya. Sedangkan perubahan tingkah laku dan gejala klinis yang terjadi pada sebagian kecil ikan uji pada kelompok kontrol diduga merupakan respon sesaat akibat proses penyuntikan larutan Phosphate Buffered Saline (PBS), dan kedua indikator tersebut sudah tidak muncul lagi pada pengamatan selanjutnya (Tabel 1). Ikan uji yang menunjukkan gejala klinis adanya lesi dan ulcer berwarna merah yang disertai nekrosis berwarna kecoklatan pasca pemberian infeksi buatan dapat dilihat pada Gambar 1.

Kematian ikan uji pada kelompok perlakuan mulai terjadi pada hari ke-2, dan terus berlangsung hingga seluruh ikan uji mengalami kematian pada hari ke-10 pasca pemberian infeksi buatan. Oleh karena itu, periode pengamatan pada penelitian ini berakhir pada hari ke-10. Data kematian ikan uji selama 

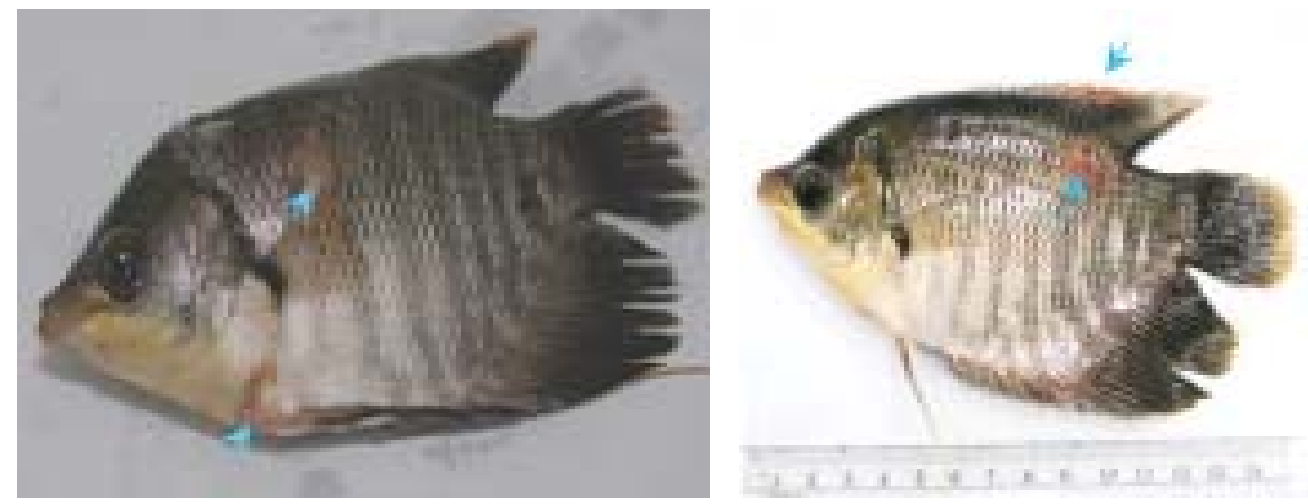

Gambar 1. Lesi dan ulcer yang disertai nekrosis pada permukaan tubuh ikan gurame (Osphronemus gouramy) yang diinfeksi spora jamur Aphanomyces invadans melalui penyuntikan secara intra muscular (IM)

Figure 1. Lesion and ulcer on body surface of giant gouramy (Osphronemus gouramy) as a result of artificially infection of Aphanomyces invadans spore was given via intra muscularly injection

periode pengamatan selengkapnya disajikan pada Tabel 2. Pada tabel tersebut terlihat bahwa kematian pada kelompok perlakuan mulai terjadi pada hari ke-2, dan kematian yang sporadis terjadi pada hari ke 4-6 yang mematikan sebanyak 21 ekor (70\%) dari total ikan uji. Sebaliknya, pada kelompok ikan kontrol tidak ditemukan adanya kematian selama periode pengamatan. Nilai-nilai tersebut mengindikasikan bahwa ikan gurama merupakan jenis ikan yang peka terhadap infeksi jamur $A$. invadans, dan jamur tersebut merupakan patogen yang ganas karena mampu mengakibatkan kematian secara akut.

Tabel 2. Mortalitas ikan uji (ekor) selama periode pengamatan (10 hari) pasca pemberian infeksi buatan dengan spora jamur Aphanomyces invadans

Table 2. Mortality of fish after injected with Aphanomyces invadans spores

\begin{tabular}{ccc}
\hline \multirow{2}{*}{$\begin{array}{c}\text { Hari ke- } \\
\text { Days- }\end{array}$} & \multicolumn{2}{c}{ Kelompok (Group) } \\
\cline { 2 - 3 } & $\begin{array}{c}\text { Perlakuan } \\
\text { Artificial infection }\end{array}$ & $\begin{array}{c}\text { Kont rol } \\
\text { Control }\end{array}$ \\
\hline 1 & - & - \\
2 & 2 & - \\
3 & 2 & - \\
4 & 7 & - \\
5 & 5 & - \\
6 & 9 & - \\
7 & 2 & - \\
8 & 1 & - \\
9 & 1 & - \\
10 & 1 & - \\
\hline Total & 30 & 0 \\
\hline
\end{tabular}




\section{Isolasi dan Sporulasi}

Isolasi jamur $A$. invadans yang dilakukan terhadap individu-individu ikan yang menunjukkan adanya bintik merah dan/atau ulcer pada permukaan tubuh diperoleh biakan jamur yang memiliki karakteristik warna, bentuk miselium serta morfologi hifa yang sama dengan jamur $A$. invadans. Isolat jamur tersebut selanjutnya dilakukan proses sporulasi untuk mengetahui beberapa karakter reproduksi yang dapat digunakan sebagai parameter kunci pada proses identifikasi. Berdasarkan hasil identifikasi terhadap isolat jamur yang diisolasi dari bintik merah dan/atau ulcer pada tubuh ikan uji, diperoleh beberapa karakter yang mengarah pada jenis jamur $A$. invadans sesuai dengan deskripsi yang dijelaskan oleh Lilley et al. (2001). Hasil selengkapnya dari pengamatan karakter tersebut disajikan pada Tabel 3, sedangkan morfologi hifa dan spora jamur dapat dilihat pada Gambar 2 \& 3 .
Menurut Lilley et al. (2001), isolasi oomycetes umumnya dilakukan dengan mengisolasi dari tempat infeksi serta kemudian ditanam pada media agar, dan proses identifikasi hingga level genus dapat dilakukan dengan metode sporulasi. A. invadans mempunyai hifa yang tidak bersepta dan memproduksi dua bentuk zoospora, yaitu zoospora primer dan sekunder. Zoospora sekunder dapat berenang bebas dan memiliki dua flagel di bagian samping (laterally biflagellata). Tidak ditemukan struktur reproduksi seksual pada isolat, dan ketiadaan struktur reproduksi seksual ini ditengarai merupakan salah satu indikator umum dari saprolegniaceae yang bersifat patogen. Taukhid (2006) menyatakan bahwa pengamatan karakter meristik-morfometrik serta eksplorasi sifat biologi jamur merupakan metode identifikasi jamur yang hingga kini masih umum dilakukan. Karakter yang sering digunakan sebagai kunci identifikasi antara lain: morfologi hifa, reproduksi aseksual, tipe

Tabel 3. Karakteristik isolat-isolat jamur yang diisolasi dari bintik merah dan/atau ulcer pada tubuh ikan gurame (Osphronemus gouramy) yang diinfesi jamur Aphanomyces invadans secara buatan

Table 3. Characteristic of the fungi were isolated from red spot and/or ulcerated test fish (Osphronemus gouramy) were artificially infected with Aphanomyces invadans

\begin{tabular}{|c|c|}
\hline $\begin{array}{c}\text { Karakteristik } \\
\text { Characteristics }\end{array}$ & $\begin{array}{l}\text { Deskripsi } \\
\text { Description }\end{array}$ \\
\hline $\begin{array}{l}\text { Bentuk hifa } \\
\text { Shape of hyphae }\end{array}$ & Aseptat \\
\hline Diameter hifa & Bervariasi, berkisar $(7,5-12,0 \mu \mathrm{m})$ \\
\hline Diameter of hyphae & Varied, ranging from (7.5 to $12.0 \mu \mathrm{m})$ \\
\hline $\begin{array}{l}\text { Tumbuh pada } 37^{\circ} \mathrm{C} \\
\text { Growing at } 37^{\circ} \mathrm{C}\end{array}$ & Tidak tumbuh (Do not grow) \\
\hline Oogonia & Tidak te ramati (Not observed) \\
\hline Zoosporangia & $\begin{array}{l}\text { Posisiny a pada ujung hifa fertil dengan diame ter yang hampir sama } \\
\text { dengan hifa (Position at the end of the fertile hyphae with a } \\
\text { diameter similar to the hyphae) }\end{array}$ \\
\hline Zoospora primer & Satu deret yang dihubungkan dengan untaian tipis cy toplasma \\
\hline Primary zoospores & A series of thin strands associated with cytoplasmic \\
\hline Clusters zoospora & Achloyd, terdiri atas 30-50 $1^{\circ}$ kista zoospora \\
\hline Clusters zoospores & Achloyd, consisting of $30-501^{\circ}$ zoospore cyst \\
\hline $\begin{array}{l}\text { Zoospora primer } \\
\text { Primary zoospores }\end{array}$ & Berdiameter 6-10 $\mu \mathrm{m}(6-10 \mu \mathrm{m}$ in diameter $)$ \\
\hline Zoospora sekunder & Motil, subspheris, reniform, biflage lla dan $\varnothing$ se kitar 4-6 $\mu \mathrm{m}$ \\
\hline Secondary zoospores & Motile, subspheris, reniform, biflagella and $\varnothing$ around 4-6 $\mu \mathrm{m}$ \\
\hline
\end{tabular}



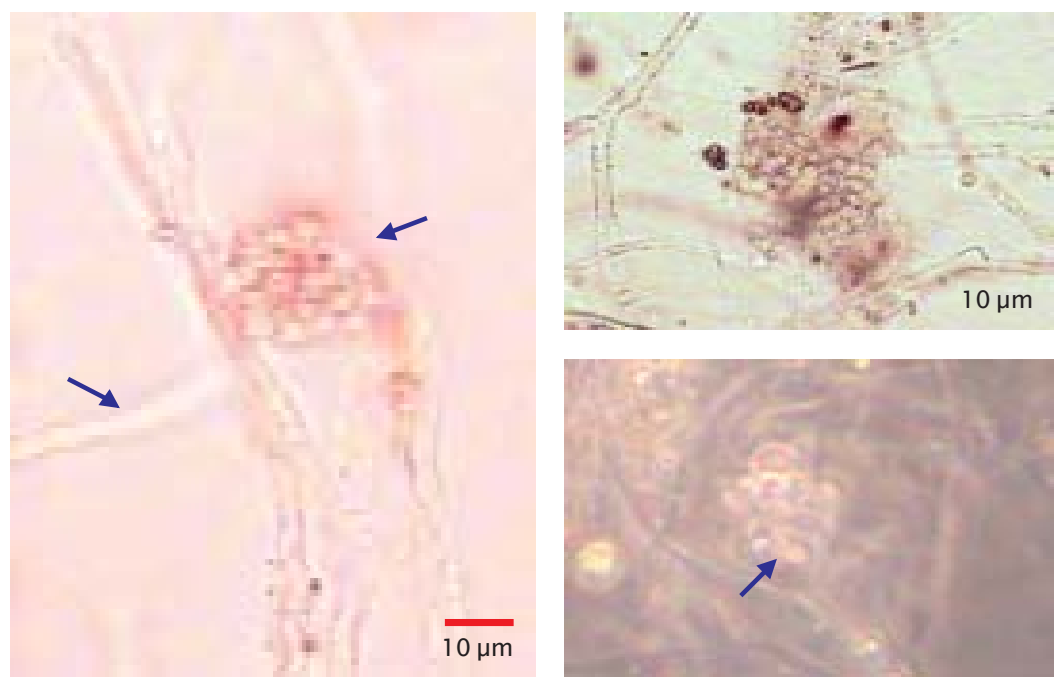

Gambar 2. Beberapa karakter morfologi jamur Aphanomyces invadans: hifa aseptat dan zoospore primer yang berbentuk cluster achloyd

Figure 2. Morphological characters of Aphanomyces invadans: aseptat hypha and achloyd cluster of primary zoospore
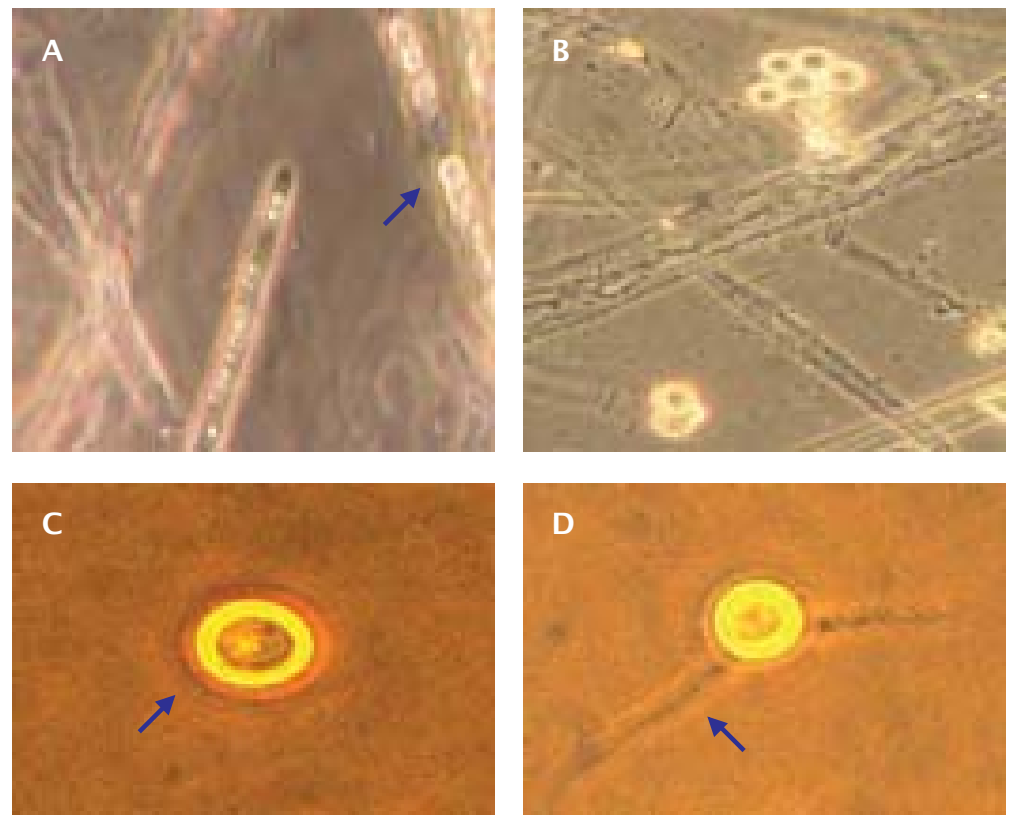

Gambar 3. Hifa fertil jamur Aphanomyces invadans yang berisi deretan tunggal zoospora yang dihubungkan dengan sitoplasma (A), zoospora primer cluster acloyd (B), zoospore sekunder motil, biflagela (C \& D)

Figure 3. Fertile hypha of Aphanomyces invadans with single row of zoospore (A), cluster achloyd of primary zoospore (B), secondary zoospore: motile and biflagellated $(C \& D)$ 
zoospore, serta beberapa karakter pertumbuhan.

\section{Histopatologi}

Hasil pengamatan secara histopatologis pada kelompok ikan yang diinfeksi secara buatan memperlihatkan adanya invasive hypae dan mikotik dermatitis granulomatosa pada jaringan otot. Hifa A. invadans ditemukan berkembang di otot sebagai perkembangan lesi dermatitis kronik ringan yang aktif. Sedangkan pada ginjal ditemukan adanya melanomacrophage center (MMC). Secara umum hasil diagnosa terhadap EUS secara histopatologis yang diperoleh pada penelitian ini sesuai dengan yang dijelaskan OIE (2010) dan Lilley et al. (2001) bahwa lesi awal pada kasus EUS ditunjukkan dengan adanya erythermatous dermatitis dan nekrosis epitel yang dikelilingi edema pada lesi awal dapat
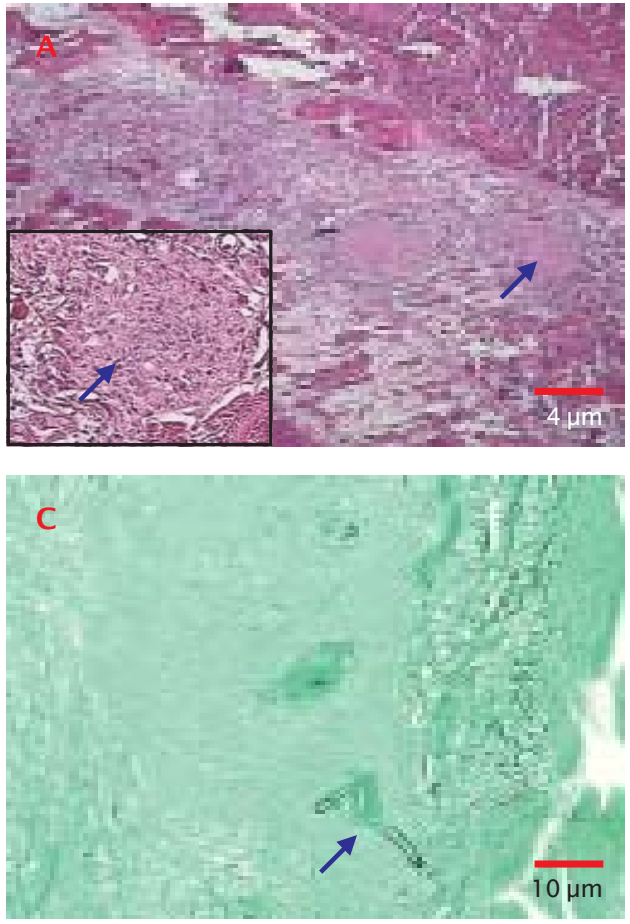

ditemukan di kulit. Selanjutnya dikatakan bahwa lesi yang khas dicirikan adanya epitheloid granuloma yang dikelilingi sejumlah hifa jamur. Penetrasi hifa jamur dikelilingi oleh inflamasi granulomatosa yang kuat sebagai ciri patologis yang umum.

Perubahan yang spesifik akibat adanya infeksi jamur $A$. invandans dapat dilihat pada Gambar 4, dan perubahan tersebut sudah terlihat jelas pada hari ke- 4 pasca pemberian infeksi buatan. Pada gambar tersebut juga terlihat adanya nekrotik granulomatosa dermatitis yang lebar ditandai dengan degenerasi floaccular otot yang berat. Keberadaan jamur pada jaringan tubuh ikan mendapatkan respon inflammatori kuat, dan kondisi tersebut terlihat dari pembentukan sel granuloma di sekeliling hifa yang menembus jaringan/organ target.

Pada tahapan lesi selanjutnya banyak ditemukan adanya nekrosis mikotik granuloma
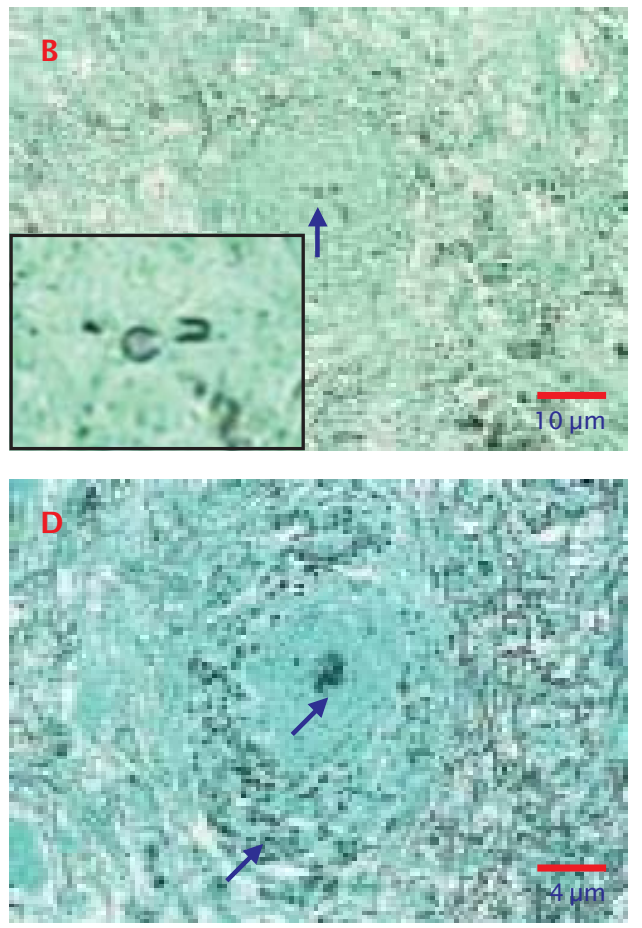

Gambar 4. Dermatitis granulomatosa (H \& E) (A), invasive hypae dan mycotic dermatitis granulomatosa (GMS) pada jaringan otot ikan gurame (Osphronemus gouramy) (B \& C), dan invasive hypae serta melano macrophage center (MMC) pada ginjal (D)

Figure 4. Dermatitis granulomatosis $(H \& E)(A)$, invasive hypae and mycotic dermatitis granulomatosa (GMS) on the muscle tissue of giant gouramy (Osphronemus gouramy) ( $B \& C)$, invasive hypae and melano macrophage center (MMC) existed on the kidney (D) 
berukuran besar di bawah fibra otot seperti terlihat pada Gambar 4 a, b, dan d yang disertai adanya hifa (invasive fungal mycelium). Pada kondisi yang lebih akut, sel jamur berkembang ke lapisan epitelioid sel dan sering dijumpai adanya degenerasi otot sarcoplasm (myophagia) dan proses penyembuhan. Lilley et al. (2001) juga menyatakan bahwa di beberapa lesi lanjutan, hifa jamur dapat terlihat menyerang abdominal viscera, yang akhirnya akan menyebabkan kematian. Sejumlah besar mikotik granuloma terlihat di ginjal, hati dan organ pencernaan termasuk limpa ikan.

Viswanath et al. (1998) dalam Lilley et al. (2001) mendapatkan bahwa pada ikan yang terinfeksi EUS memperlihatkan adanya penetrasi $A$. invadans di esophagus dan saraf tulang belakang serta tulang inter-muskular, sedangkan pada lambung dan usus tidak teramati adanya perubahan histopatologi. Selanjutnya Lilley et al. (2001) menambahkan bahwa pada ginjal ikan yang terkena EUS memperlihatkan adanya degenerasi organ, dan ditemukan adanya nekrosa acinar dengan eosinofil dan infiltrasi sel inflammatori pada organ pankreas. Pada hati mengalami degenerasi saluran hepatik yang memungkinkan adanya keterlibatan infeksi bakteri dan/atau jamur.

Berdasarkan hasil yang diperoleh pada penelitian ini, secara umum dapat dikatakan bahwa diagnosa penyakit EUS pada ikan yang didasarkan pada tampilan gejala klinis (patologis-anatomis) yang dipadukan dengan salah satu atau secara bersamaan dengan isolasi patogen dan/atau histopatologis memberikan tingkat sensitivitas dan spesifisitas yang sangat tinggi. Diagnosa penyakit EUS dapat dilakukan berdasarkan gejala klinis yang dikonfirmasi dengan isolasi jamur pada media tumbuh dan/atau histopatologis. Validitas metode diagnosa tersebut masuk dalam kategori A (gold standard), baik untuk tujuan diagnosa presumtif maupun konfirmatif (OIE, 2010). Selanjutnya disebutkan bahwa metode diagnosa lain yang memenuhi kategori A untuk tujuan diagnosa konfirmatif adalah teknik deteksi DNA melalui polymerase chain reaction (PCR) terhadap isolat murni jamur; namun teknik tersebut masuk kategori D untuk tujuan diagnosa presumtif.

\section{KESIMPULAN}

- Diagnosa penyakit Epizootic Ulcerative Syndrome (EUS) pada ikan yang disebab- kan oleh infeksi jamur Aphanomyces invadans dapat dilakukan melalui integrasi pendekatan gejala klinis (patologisanatomis) dengan isolasi jamur parasitik (untuk mengetahui karakteristik eko-biologi jamur) dan/atau histopatologis.

- Metode diagnosa penyakit EUS melalui perpaduan antara gejala klinis dengan isolasi jamur parasitik dan histopatologis memiliki sensitivitas dan spesifisitas tinggi, dan merupakan "international gold standard" untuk diagnosa penyakit tersebut.

- Validitas penggabungan metode yang dikembangkan (verifikasi metode) dan diterapkan pada penelitian ini dapat digunakan untuk tujuan diagnosa presumtif maupun konfirmatif terhadap keberadaan penyakit EUS di seluruh wilayah Indonesia.

\section{UCAPAN TERIMA KASIH}

Penulis mengucapkan terima kasih kepada Bapak Teguh Samudro dan Asep Dadang Koswara atas arahan dan dukungannya selama berlangsungnya penelitian serta penulisan manuskrip ini. Kepada Mark. W. Vandersea dari National Oceanic Atmospheric Administration (NOAA)-Amerika Serikat, atas saran dan bantuannya, terutama atas kesediaannya memberikan standard reference material (SRM) produk polymerase chain reaction (PCR) sebagai kontrol positif.

\section{DAFTAR ACUAN}

Callinan, R.B. 1994. Red spot disease-EUS in Australia. In: Roberts, R.J., Campbell, B., and MacRae, I.H. (Eds). Proceeding of the ODA Regional Seminar on Epizootic Ulcerative Syndrome, 25-27 January 1994. Aquatic Animal Health Research Institute, Bangkok, p. 82-88.

Fraser, G.C., Callinan, R.B., \& Calder, L.M. 1992. Aphanomyces species associated with red spot disease: an ulcerative disease of estuarine fish from eastern Australia. Journal of Fish Diseases, 15: 173-181.

Hatai, K., Egusa, S., Takahashi, S., \& Ooe, K. 1977. Study on the pathogenic fungus of mycotic granulomatosis-I. Isolation and pathogenicity of the fungus from cultured ayu (Plecoglossus altivelis) infected with the disease. Fish Pathology, 11 (2): 129-133.

Hatai, K. \& Egusa, S. 1978. Studies on the pathogenic fungus of mycotic granulomatosisIIO. Some of the note on the MG-fungus. 
Fish Pathology, 13(2): 85-89. (In Japanes, English abstract).

Lilley, J.H., Thompson, K.D., \& Adams, A. 1997, Characterization of Aphanomyces invadans by Electrophoretic and Western Blot Analysis, Diseases of Aquatic Organisms, 30: 187-197.

Lilley, J.H., Callinan, R.B., Chinabut, S., Kanchanakhan, S., MacRae, I.H., \& Phillips, M.J. 1998. Epizootic Ulcerative Syndrome (EUS) Technical Handbook. The Aquatic Animal Health Research Institute, Bangkok, $88 \mathrm{pp}$.

Lilley, J.H., Callinan, R.B., Chinabut, S., Kanchanakhan, S., MacRae, I.H., \& Phillips, M.J. 2001. Epizootic Ulcerative Syndrome (EUS) Technical Handbook (second edition). The Aquatic Animal Health Reseach Institute, Bangkok.

Miyazaki, T. \& Egusa, S. 1972. Studies on mycotic granulomatosis in fresh water fishesI. Mycotic granulomatosis in goldfish. Fish Pathology, 7: 15-25 (In Japanes).

OIE. 2010. Epizootic Ulceration Syndrome, Manual of Diagnostic Tests for Aquatic Animals, Chapter 2.1.10, Office Internationale des' Epizootic.

Pradhan, K.P., Morgan, C.V., Shankar, K.M., Kumar, B., \& Devaraja, G. 2007. Yearling Indian Major Carps Resist Infection Againts the Epizootic Ulcerative Syndrome Pathogen, Aphanomyces invadans. Current Science, 92: No 25.
Roberts, R.J., Frerichs, G.N., \& Millar, S.D. 1990. Epizootic Ulcerative Syndrome-the current position. In: Shariff, M., Subasinghe, R.P., and Arthur, J.R. (Eds.), Diseases in Asian Aquaculture 1. Fish Health Section, Asian Fisheries Society, Manila, p. 431-436.

Roberts, R.J., Willoughby, L.G., \& Chinabut, S. 1993. Mycotic aspects of epizootic ulcerative syndrome (EUS) of Asian fishes. Journal of Fish Diseases, 16: 169-183.

Roberts, R.J., Campbell, B. and MacRae, I.H. (1994) Proceeding of the ODA Regional Seminar on Epizootic Ulcerative Syndrome, 25-27 January 1994, Aquatic Animal Health Research Institute, Bangkok, p. 82-88.

Taukhid. 2006. Penyakit mikotik pada ikan dan udang (eksisting dan eksotik). Bahan pelatihan petugas Pengendali Hama dan Penyakit Ikan (PHPI). (tidak dipublikasikan).

Tonguthai, K. 1985. A preliminary account of ulcerative fish diseases in the Indo-Pasific region (a comprehensive study based on Thai experiences). National Inland Fisheries Institute, Bangkok, 39 pp.

Willoughby, L.G. \& Robert R.J. 1994. Improved Methodology for Isolation of The Aphanomyces Fungal Pathogen of Epizootic Ulcerative Syndrome (EUS) in Asian Fish, Journal of Fish Diseases, 17: 541-543.

Willoughby, L.G., Roberts, R.J., \& Chinabut, S. 1995. Aphanomyces invaderis sp. Nov., the fungal pathogen of freshwater tropical fishes affected by epizootic ulcerative syndrome (EUS). Journal of Fish Diseases, 18: 273-275. 